\title{
Improving agricultural extension services in Moro Local Government Area of Kwara State, Nigeria
}

\author{
E. O. Imoloame ${ }^{1 *}$ and A. O. Olanrewaju ${ }^{2}$ \\ ${ }^{1}$ Kwara State University, Malete.P. M. B. 1530, Ilorin, Nigeria. \\ ${ }^{2}$ Kwara State Agricultural Development Programme, Ilorin, Nigeria.
}

Accepted 25 June, 2013

\begin{abstract}
A survey was conducted in Moro Local Government Area of Kwara State in 2012 by administering structured questionnaire to $\mathbf{3 0}$ farmers each from $\mathbf{5}$ villages in the Local Government. The aim was to determine the quality of extension service in Moro Local Government Area with a view to improving it. Results show that most of the farmers $(28.2 \%)$ are in the age group of 21 to 30 years. A greater percentage of the farmers (53.3\%) are subsistence farmers cultivating between 1 to 2 hectares (ha) of land. Although, extension services were provided long time ago $(71.1 \%)$, mainly by non-governmental organizations (NGOs) and needs assessment were not conducted first before transferring innovations $(63.9 \%)$, the quality of extension service was good $(51.2 \%)$ and has resulted in improved skills $(89.3 \%)$ and productivity of the farmers. However, it was recommended that there is need to further improve extension service in the Local Government to ensure the achievement of the desired objectives.
\end{abstract}

Key words: Moro Local Government, extension service quality, improving services.

\section{INTRODUCTION}

Agriculture is important to the Nigerian economy as it engages $70 \%$ of the labour force and contributes over $40 \%$ of the Gross Domestic Product (GDP) (FMARD, 2000). It provides food for the teeming population and raw materials for industries. The sector is however faced with mirage of problems which militate against optimizing its potential. Some of the constraints include low productivity, poor marketing and distribution infrastructure, inadequate access to credit, weak extension services and inadequate database among others (FMARD, 2000). Extension implies informing, teaching and advising farmers about new and improved technologies and getting a feedback from them (farmers) to research. This is with a view to helping the farmers improve their productivity, earn more income and improve their standard of living (Asumugha et al., 2009). Therefore, agricultural extension brings about changes, through education and communication in farmers attitude, knowledge and skills. The roles of agricultural extension are to building capacity of farmers and help them to make informed decisions. Sinkaye (2005) equates help in extension to empowering all members of the farm house holds to ensure holistic development. In spite of the lofty role of agriculture extension, the Nigerian agricultural extension service is bedeviled by several problems as identified by Agbamu (2005), such as inadequacy and instability of funding, poor logistic support for field staff, use of poorly trained personnel at local level, ineffective agricultural research - extension linkages, insufficient and inappropriate agricultural technologies for farmers, disproportionate number extension agent to farm family ratio and lack of clientele participation in programme development. Others are poor input supply, irregular evaluation of extension programmes and policy, 
institutional and programme instabilities of National agricultural extension systems.

The problem of agricultural extension and indeed technology delivery became prominent with the expiration of the World Bank component of agricultural extension funding arrangement. Withdrawal of funding and fierce competition for resources from the national budget among different economic sections has substantially reduced the funding available for agricultural technology delivery (Chukwuone et al., 2006). Since the late 1990s, inadequate funding has led to the virtual collapse of research and extension institutions that provided services to small farmers and rural communities in Nigeria (Omotayo, 2004). Considering that improved technology delivery in Nigeria's agriculture is the veritable means of bringing about improvement in the current levels of agricultural production and resource productivity, promoting technology delivery is imperative. Several researchers (Adebayo et al., 1999; Agwu and Chukwuone, 2005; Ikpi, 2002; Ogunbameru, 2005; Omotayo, 2004) have shown that one of the major lessons learned from the past extension programmes in Nigeria is that it is not possible for government alone to support extension programme in all its ramifications, and that private sector needs to play a more active role in both funding and the physical transfer of the available improved technologies. In pursuance of more private involvement in agricultural technology delivery, some innovative mechanisms derived from the Nigerian government stance in privatization policy, are being considered. In this regard, cost sharing is seen as a tenable privatization policy option (Chukwuone et al., 2006).

Cost sharing is a system where beneficiaries of services pay user fee. It is a privatization strategy which entails paying a fee for services and advice which formerly was free of charge (Rivera and Cary, 1997). It is similar to partial commercialization, which involves the reorganization of public enterprise and the introduction of commercialization principles into the enterprise operation such as user charge, with the aim of realizing funds for the enterprise (United Nations, 1995). However, Nnaemeka et al. (2006) reported some constraints to cost - sharing arrangement as weak institutional development, uncertainties inherent in agriculture, poor cooperation from farmers and weak agricultural extension / technology delivery mechanisms. Farmers and extension agents were of the view that enacting enabling legislation for cost - sharing, building political support and disseminating information on cost-sharing of agricultural technology delivery could help facilitate costsharing arrangement (Nnaemeka et al., 2006). Other measures include increasing the number of extension staff or reducing the area of coverage by an extension agent and establishment of vibrant farmers cooperate to serve as avenue for collecting the charges from farmers. Since the Kwara State Government is interested in revolutionizing its agriculture, there is a great need to make the extension service in Moro Local Government Area in particular and Kwara State in general effective, which is a sine- qua- non to the achievement of its goal.

The objective of this paper is to determine the quality of extention services and the effects on the skills and productivity of farmers and suggest ways to improve them in Moro Local Government Area of Kwara State.

\section{METHODOLOGY}

A field survey was conducted in Moro Local Government Area of Kwara State in 2012. 5 villages were selected at random within Moro Local Government for the survey. They are: Village I (Malete), Village II (Elemere), Village III (Shao), Village IV (Jehunkanu) and Village V (Omini). Structured questionnaire was used to elicit information from the farmers and were administered by extension officers on 30 farmers in each of the villages adding up to a total of 150 farmers that ware sampled. The questionnaire sought information on the method of extension delivery, effect and quality of extension services provided, etc. in Moro Local Government Area. The responses were expressed in simple percentages and determined by expressing the frequency of responses over the total population of farmers multiplied by 100 .

\section{RESULTS AND DISCUSSION}

\section{Socio-demographic characteristics of farmers}

The socio-demographic characteristics of farmers in the five villages of Moro Local Government Area of Kwara State are presented in Table 1. It shows that a greater proportion of the farming population falls within the age range of 21 to 50 years, which constitutes $79 \%$ of the farming population. The age groups of 21 to 30 years form the highest combined percentage of the farming population. This is an evidence that majority of the farmers in this 'local government area' are youths who can be considered to be energetic for work (Kolo, 2004). A larger percentage of farmers in each of the villages sampled and the combined population are males, married and in agriculture on full-time basis (Table 1). The fulltime status of most of the farmers underscores the importance of agriculture as an employer of labour and as a way out of the worsening employment problem in Nigeria. Also, the fact that majority of the farmers are married will enable them receive various forms of assistance from their wives and children both at home and on the farm. A greater percentage of the farming population has primary education $(54.1 \%)$, while $26 \%$ are illiterate. Only $5 \%$ of the combine farming population have tertiary education and are present in Elemere and Shao villages of Moro Local Government Area (Table 1).

\section{Area cultivated, cropping system and types of livestock produced}

Table 2 shows the type of crops and livestock produced, 
Table 1. Socio-demographic characteristics of farmers in 5 villages of Moro Local Government Area of Kwara State expressed as percentage of number of respondents.

\begin{tabular}{|c|c|c|c|c|c|c|}
\hline \multirow{2}{*}{ Parameter } & \multicolumn{6}{|c|}{ Villages } \\
\hline & $1 \%$ & II \% & III \% & IV \% & V \% & Combine $\%$ \\
\hline \multicolumn{7}{|l|}{ Age (year) } \\
\hline$<20$ & 6.7 & 20.7 & 23.3 & 3.3 & 6.7 & 12.1 \\
\hline $21-30$ & 26.7 & 31.0 & 26.7 & 3.3 & 53.3 & 28.2 \\
\hline $31-40$ & 50.0 & 17.2 & 20.0 & 13.3 & 20.0 & 24.1 \\
\hline $41-50$ & 16.6 & 3.5 & 23.3 & 73.3 & 16.7 & 26.7 \\
\hline$>50$ & - & 27.6 & 6.7 & 6.7 & 3.3 & 8.9 \\
\hline \multicolumn{7}{|c|}{ Marital status } \\
\hline Married & 93.3 & 65.4 & 66.7 & 73.3 & 80 & 75.7 \\
\hline Single & 6.7 & 34.6 & 33.3 & 26.7 & 20 & 24.3 \\
\hline \multicolumn{7}{|l|}{ Gender } \\
\hline Male & 72.4 & 64.3 & 70.0 & 50.0 & 55.6 & 62.5 \\
\hline Female & 27.6 & 35.7 & 30.0 & 50.0 & 44.4 & 37.5 \\
\hline \multicolumn{7}{|c|}{ Farming status } \\
\hline Full - time & 79.3 & 57.1 & 53.6 & 66.7 & 48.3 & 61.0 \\
\hline Part - time & 20.7 & 42.9 & 46.4 & 33.3 & 51.7 & 39.0 \\
\hline \multicolumn{7}{|c|}{ Educational status } \\
\hline Illiterate & 33.3 & 32.1 & 7.7 & 30.0 & 26.7 & 26.0 \\
\hline Primary & 53.3 & 35.7 & 61.5 & 56.7 & 63.3 & 54.1 \\
\hline Secondary & 13.3 & 21.5 & 23.1 & 13.3 & 3.3 & 14.9 \\
\hline Tertiary & - & 10.7 & 7.7 & - & 6.7 & 5.0 \\
\hline
\end{tabular}

cropping system and size of land cultivated by farmers. Most of the farmers are subsistence farmers as they cultivate between 1 to 2 ha of land with major crops like legumes, root and tuber and cereal crops and most of the farmers adopted monocropping. Also, most of the farmers $(65.4 \%)$ are engaged in poultry production, while pigs and ducks are not produced probably due to the predominance of Muslims in Kwara State who forbid pork meat.

\section{Extension activities in Moro Local Government Area}

The response of farmers on extension activities in Moro Local Government Area is presented in Table 3. Most of the farmers in the villages sampled and the combined farming population accepted that extension service was provided for them a long time ago and that nongovernmental organizations (NGO) provided most of the extension service. Only a small percentage $(17.5 \%)$ of the farming population claims that government agencies provided them with extension service. Also, most farmers are aware of the plan to implement extension programme in their villages by NGOs. The Kwara State governments do not seem to be meeting its obligation of providing adequate extension services to this local government area, as it has abandon the provision of extension services to the private sector. This situation could be as a result of poor funding of Agricultural Development Programme which is the state organ responsible for providing extension services. This agrees with the report of Agbamu (2005) that Nigeria extension service is bedeviled by several problems which include inadequacy and instability of funding and poor logistic support for field staff. According to Anderson and Feder (2003), withdrawal of funding with the expiration of the World Bank of the agricultural extension funding arrangement and fierce competition for resources from the national budget among different economic sectors has substantially reduced the funding available for agricultural technology delivery in Nigeria. Omotayo (2004) reported that since the late 1990's, inadequate funding has led to the virtual collapse of research and extension institutions that provided services to small farmers and rural communities in Nigeria.

Table 4 shows the response of the farmers on the perceived reason extension service was provided a long time ago and why some innovations were not adopted by 
Table 2. Response of farmers in Moro Local Government Area on farming system, area of land cultivated and types of crops and livestock reared.

\begin{tabular}{|c|c|c|c|c|c|c|}
\hline \multirow{2}{*}{ Parameter } & \multicolumn{6}{|c|}{ Villages } \\
\hline & $1 \%$ & II \% & III \% & IV \% & V \% & Combine $\%$ \\
\hline \multicolumn{7}{|c|}{ Type of crops cultivated } \\
\hline Cereals & 20.0 & 33.3 & 14.3 & 10.0 & 20.0 & 19.4 \\
\hline Legumes & 60.0 & 33.3 & 53.6 & 46.7 & 73.3 & 53.4 \\
\hline Tuber and root & 20.0 & 23.3 & 21.4 & 40.0 & 6.7 & 22.3 \\
\hline Oil crop & - & 3.3 & 3.6 & - & - & 1.4 \\
\hline Vegetable & - & 6.7 & - & - & - & 1.4 \\
\hline Fruits & - & - & 7.1 & 3.3 & - & 2.1 \\
\hline \multicolumn{7}{|c|}{ Cropping system practiced } \\
\hline Mono cropping & 79.3 & 72.4 & 58.3 & 20.0 & 89.7 & 64 \\
\hline Mixed cropping & 20.7 & 20.7 & 29.2 & 73.3 & 3.4 & 29.4 \\
\hline Mixed farming & - & 6.7 & 12.5 & 6.7 & 6.9 & 6.6 \\
\hline \multicolumn{7}{|c|}{ Area of land cultivated (ha) } \\
\hline$<1$ & 20.0 & 20.7 & 14.8 & - & 6.7 & 12.4 \\
\hline $1-2$ & 60.0 & 44.8 & 51.9 & 33.3 & 76.7 & 53.3 \\
\hline $3-4$ & 20.0 & 17.2 & 25.9 & 63.3 & 10.0 & 27.3 \\
\hline $5-6$ & - & 3.4 & 3.7 & 3.3 & 3.3 & 2.7 \\
\hline$>6$ & - & 13.8 & 3.7 & - & 3.3 & 4.2 \\
\hline \multicolumn{7}{|c|}{ Types of livestock } \\
\hline Poultry & 73.3 & 56.7 & 53.6 & 46.7 & 96.7 & 65.4 \\
\hline Sheep & 10.0 & 6.7 & 7.1 & 23.3 & 3.3 & 10.1 \\
\hline Goat & 16.7 & 3.3 & 14.3 & 26.7 & - & 12.2 \\
\hline Pig & - & - & - & - & - & - \\
\hline Fish & - & 20.0 & 17.9 & - & - & 7.6 \\
\hline Duck & - & - & - & - & - & - \\
\hline Others & - & 13.3 & 7.1 & 3.3 & - & 4.7 \\
\hline
\end{tabular}

them. Most of the farmers (75.4\%) attributed the delay in the provision of extension service to lack of funds. Similarly, most farmers $(57.1 \%)$ did not adopt some of the innovations due to the fact that they do not only lacked relative economic advantage over the old practices, they are also expensive to adopt. This result agrees with Oni et al. (2008) that the more economically beneficial an innovation is, the greater the rate of adoption. Table 5 presents the response of farmers on teaching methods used to inform and transfer new technology to them. Most farmers said extension meetings and result demonstration were used to transfer technology to them. However, most of the farmers in each of the villages and combined farming population admitted that farmers' needs are not assessed before a new technology is provided for them. The use of only extension meetings and result demonstrations may be grossly inadequate to effectively transfer innovation to farmers. Pretty and Volouche (1997) mentioned the extension methods that extension staff should draw from to address specific needs.
They includes: (a) Individual farm and home visit for follow up, (b) Group method: demonstrations to farmers groups, field days, (c) Mass method to create awareness and reach large population at a time, (d) farmers trainings and (e) participatory methods in which extension staff work with farmers to analyze current situations and problems and determine appropriate action for selfreliance. An example is farmer field schools (FFS). Also, the failure of extension service to start with needs assessment, might have resulted in the rejection of some of the innovations by farmers. Failure to carry out needs assessment was wrong because for a successful extension activity, it is necessary that extension worker must collect the relevant data about an area and that it will enable him to identify areas of constraints that need extension attention (Ani, 2007).

\section{Response of farmers on the effect of extension services on their skills and productivity}

Response of farmers on effect of extension service on 
Table 3. Response of farmers on the extension activities in Moro Local Government Area of Kwara State, 2012.

\begin{tabular}{|c|c|c|c|c|c|c|}
\hline \multirow{2}{*}{ Parameter } & \multicolumn{6}{|c|}{ Villages } \\
\hline & $1 \%$ & II \% & III \% & IV \% & V \% & Combine $\%$ \\
\hline \multicolumn{7}{|c|}{ Last time extension service was provided } \\
\hline Few days ago & - & 13.8 & 6.7 & - & - & 4.1 \\
\hline Recently & 3.3 & 17.2 & 3.3 & 46.7 & - & 14.1 \\
\hline Long time ago & 90.0 & 51.7 & 66.7 & 50.0 & 100.0 & 71.7 \\
\hline Never & 6.7 & 17.2 & 23.3 & 3.3 & - & 10.1 \\
\hline \multicolumn{7}{|c|}{ Which agency provided you with agric extension service } \\
\hline Government agency & 6.7 & 23.3 & 21.4 & 26.7 & 10.0 & 17.6 \\
\hline Non-governmental organization & 93.3 & 60.0 & 67.9 & 63.3 & 86.7 & 74.2 \\
\hline Fate based organized & - & 6.7 & 10.7 & - & 3.3 & 4.1 \\
\hline Others - specify & - & 10.0 & - & 10.0 & - & 4 \\
\hline \multicolumn{7}{|c|}{ Are you aware of any plan for an extension service in future } \\
\hline Yes & 89.7 & 20.7 & 50 & 73.3 & 93.3 & 65.4 \\
\hline No & 10.3 & 79.3 & 50 & 26.7 & 6.7 & 34.6 \\
\hline \multicolumn{7}{|c|}{ Which organisation wants to execute plan } \\
\hline Government agency & 20.7 & 28.6 & 42.5 & 53.8 & 18.5 & 32.8 \\
\hline Non governmental organization & 75.9 & 61.9 & 53.8 & 46.2 & 70.4 & 61.6 \\
\hline Fate based & 3.4 & 9.5 & 3.3 & - & 11.1 & 5.5 \\
\hline
\end{tabular}

Table 4. Response of farmers on the perceived reason extension service was provided long time ago and for not adopting some of the innovations extended to them.

\begin{tabular}{lcccccc}
\hline \multirow{2}{*}{ Parameter } & \multicolumn{5}{c}{ Villages } \\
\cline { 2 - 7 } & $\mathbf{I} \%$ & $\mathbf{I I} \%$ & $\mathbf{I I I} \%$ & $\mathbf{I V} \%$ & V \% & Combine \% \\
\hline Reason for providing extension service long time ago & & & & & & \\
\hline Lack of fund & 83.3 & 67.9 & 59.3 & 76.7 & 90.0 & 75.4 \\
Lack of adequate extension officer & - & 10.9 & 11.1 & 3.3 & - & 5.1 \\
Village not accessible & 13.3 & 17.9 & 25.9 & 16.7 & 10.0 & 16.8 \\
Village do not want extension service & 3.3 & 3.5 & 3.7 & 3.2 & - & 2.7 \\
& & & & & & \\
Reasons for not adopting some innovation & & & & & & 4.7 \\
Complex in nature & - & 10.0 & 10.0 & 3.3 & - & 57.1 \\
No relative advantage & 80.0 & 36.7 & 33.3 & 6.7 & 76.7 & 5.4 \\
Not related to previous experience & - & 10.0 & 6.7 & 3.3 & 6.7 & 22.8 \\
Expensive to adopt & 10.0 & 33.3 & 33.3 & 26.7 & 10.0 & 2.7 \\
Not meeting need & 10.0 & 10.0 & 16.7 & 10 & 6.7 & 10.7 \\
Others specify & & & & & & \\
\hline
\end{tabular}

their skills and productivity is presented in Table 6. It shows that most of the farmers in the 5 villages and the combined population are of the opinion that extension service provided has improved their skills and productivity and it is of good quality, although extension service was provided to the farmer a long time ago. Table 7 shows the response of farmers on the principles of sharing cost of extension delivery with the farmers. Overwhelming percentage of farmers in the 5 villages sampled and their combined population agree that they will share the cost of providing extension service. This could be due to the realization on the part of the farmers that there is need to cooperate with the government to improve the mechanism of extension delivery system in Nigeria. This supports the findings of several researchers (Adebayo et al., 1999; Agwu and Chukwuone, 2005; Ikpi, 2002; 
Table 5. Response of farmers on teaching methods used to inform and transfer of innovations.

\begin{tabular}{|c|c|c|c|c|c|c|}
\hline \multirow{2}{*}{ Parameter } & \multicolumn{6}{|c|}{ Villages } \\
\hline & $1 \%$ & II \% & III \% & IV\% & V \% & Combine \% \\
\hline \multicolumn{7}{|c|}{ Extension methods used for communication } \\
\hline Extension meetings & 63.3 & 55.2 & 27.6 & 31.0 & 76.7 & 50.8 \\
\hline Result demonstration & 33.3 & 27.6 & 51.7 & 55.2 & 16.7 & 36.9 \\
\hline Method demonstration & - & 3.4 & 3.4 & 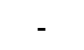 & 3.3 & 2.0 \\
\hline Mass media & 3.3 & 13.8 & 17.2 & 13.8 & 3.3 & 10.3 \\
\hline Others specify & - & - & - & - & - & - \\
\hline \multicolumn{7}{|c|}{ Are needs of farmers assessed first before the transfer of technology } \\
\hline Yes & 46.7 & 24 & 23.3 & 50 & 36.7 & 36.1 \\
\hline No & 53.3 & 76 & 76.7 & 50 & 63.3 & 63.9 \\
\hline
\end{tabular}

Table 6. Response of the farmers on the effect of extension service on their skills, productivity.

\begin{tabular}{lcccccc}
\hline \multirow{2}{*}{ Parameter } & \multicolumn{4}{c}{ Villages } \\
\cline { 2 - 7 } & $\mathbf{I} \%$ & $\mathbf{I I} \%$ & $\mathbf{I I} \%$ & $\mathbf{I V} \%$ & $\mathbf{V} \%$ & Combine \% \\
\hline Has extension service improved your skills & & & & & & \\
\hline Yes & 96.6 & 100.0 & 96.6 & 60.0 & 93.3 & 89.3 \\
No & 3.3 & 0.0 & 3.3 & 40.0 & 6.7 & 10.7 \\
Has it increased your productivity & & & & & & \\
Yes & 93.3 & 28.6 & 43.3 & 56.7 & 93.1 & 63.0 \\
No & 6.7 & 71.4 & 56.7 & 43.3 & 6.9 & 37.0 \\
Quality of extension service & & & & & & \\
Excellent & & & & & & \\
Very good & 6.7 & 6.7 & 3.3 & 3.3 & 0.0 & 4.0 \\
Good & 40.0 & 40.0 & 30.0 & 23.3 & 10.3 & 28.7 \\
Poor & 40.0 & 50.0 & 46.7 & 33.3 & 86.2 & 51.2 \\
& 13.3 & 3.3 & 20.0 & 40.0 & 3.4 & 16 \\
\hline
\end{tabular}

Table 7. Response of farmers on the principles of sharing cost of providing extension service with the extension service provider.

\begin{tabular}{lcccccc}
\hline \multirow{2}{*}{ Parameters } & \multicolumn{7}{c}{ Villages } \\
\cline { 2 - 7 } & I \% & II \% & III \% & IV \% & V \% & Combine \% \\
\hline Cost sharing & & & & & & \\
\hline Yes & 100.0 & 100.0 & 96.1 & 77.7 & 100.0 & 94.8 \\
No & 0.0 & 0.0 & 3.9 & 22.3 & 0.0 & 5.2 \\
\hline
\end{tabular}

Ogunbameru, 2005; Omotayo, 2004) that one of the major lessons learned from the past extension programmes in Nigeria is that it is not possible for government alone to support extension programme and that private sector needs to play a more active role in both funding and the physical transfer of the available improved technologies and that some innovative mechanisms such as cost sharing with the farmers should be considered in pursuance of more private involvement in agricultural delivery.

\section{CONCLUSION AND RECOMMENDATIONS}

It can be concluded that though extension services provided in Moro Local Government Area has led to improvement of the skills and productivity of farmers, there is still need to do more to improve the extension delivery system in order to make it more effective. Some of the improvements to be made are:

a) State government should be more active and take a 
leading position in providing extension services to farmers on a more regular basis.

b) State government should coordinate the activities of other extension delivery systems like the nongovernmental organizations and make them compliment the efforts of the state agricultural development programme for effectiveness of the system and enhanced service delivery to farmers.

c) In order to improve the quality of extension service, needs assessment should be conducted and involvement of farmers in programme development should be encouraged.

d) State government should increase the funding to Kwara State Agricultural Development Agency through better budgetary allocations and cost-sharing by the 3 tiers of government, support from development partners, the private sector, NGOs and farmers' organizations.

e) Government should explore ways of privatizing or partially commercializing the state's extension delivery system since farmers have agreed to share the cost of providing effective extension services with other stake holders.

\section{REFERENCES}

Adebayo KI, Idowu IA, Omotayo AM, Olunuga BA, Apantaku SO (1999) (1999). An Appraisal of the Prospects and Constraints to Sustainable Funding of Osun State Agricultural Development Programme, J. Agric. Ext. 3:28-38.

Agbamu JU (2005). Problem and Prospects of Agricultural Extension Service in Developing Countries. In: Agricultural Extension in Nigeria. S.F. Afolayan (Ed.) llorin AESON pp. 159 -169.

Agwu AE, Chukwuone NA (2005). Funding of Agricultural Extension in a Democratic and Deregulated Economy. The Cost Sharing Approach. J. Agric. Ext. 8:90-98.

Ani AO (2007). Agricultural Extension: A Pathway for Sustainable Agricultural Development. Apani Publication in Partnership with Loud Books (Publishers) Nigeria, P. 179.

Chukwuone NA, Agwu AE, Ozor N (2006). Constraints and Strategies Toward Effective Cost Sharing of Agricultural Technology Delivery in Nigeria. Perception of Farmers and Agricultural Extension Personnel - J. Int. Agric. Ext. Edu.13:29 -41.

Contado TE (1997). Formulating Extension Policy. In: Improving Agricultural Extension: A Reference Manual (Swason et al. Eds.) Rome FAO.

FMARD (2000). Agricultural in Nigeria: The New Policy Thrust.

Ikpi A (2001). Nigeria's Agriculture Sector Assessment: Issues of Technology Development Transfer, Report Prepared for the United State Agency for International Development, Rural Sector Strategy Study. Technology Development and Transfer in Agriculture.
Koyenikan MJ (2008). Issues for Agricultural Extension Policy in Nigeria. J. Agric. Ext. 12(2):52-57.

Ogunbameru BO (2005). Funding Agricultural Extension Services in Nigeria. In: S.F. Adedoyin (Ed.). Agricultural Extension in Nigeria, pp. 177-188.

Ogunbameru BO, Undiandeye UC, Ani AO (2008). Agricultural Extension Methodologies. Apani Publications and Loud Books (Publishers) Nigeria, P. 151.

Omotayo A (2004). Institutional Arrangement for Effective Participation of the Private Sector and other Non-government Service Providers Extension Delivery in Nigeria. In: Adedoyin SF, Adeokun OA (Eds.). Institutional Frameworks and Processes for Enhancing Effectiveness of Extension Service. Proceedings of the $1^{\text {st }}$ South West AESON Workshop, pp. 16-23.

Rivera WM, Cary JW (1997). Privatization of Agricultural Extension. In: Swanson BE, Bentz RP, Sofranko AJ (Eds.) Improving Agricultural Extension: A Reference Manual. pp. 203-212.

Sinkaiye T (2005). Agricultural Extension Participating Methodologies and Approaches in Agricultural Extension in Nigeria, Afolayan SF (Ed) Ilorin AESON, pp. 220-233.

United Nations (1995). Co-operate Experience with Privatization Policy Insight and Issues. United Nations Conference on Trade and Development, New York and Geneva, pp. 1-24. 